N. Muzychenko

\title{
THE STRATEGIC ROLE OF GAS TRANSPORT INFRASTRUCTURE DEVELOPMENT IN ENSURING THE EU'S ENERGY SECURITY.
}

The main driving force in the development of the EU economy has traditionally been the energy component.

The existing shortage of own natural gas production in the EU countries determines the urgency of the issue of diversification of sources and ways of energy supply to the domestic market of European countries. The European gas market combines extensive opportunities for the import of natural gas through pipelines and the use of liquefied natural gas.

In order to reduce energy dependence, the countries of the European Union are trying to diversify gas supplies by expanding the range of suppliers and methods of transportation.

The article investigates the ways to diversify sources of natural gas supply to EU countries in the context of new pipeline continental and transcontinental projects implementation.

Attention is paid to the direct dependence of individual European countries on external natural gas suppliers as well as to measures taken by the EU to prevent gas monopolization.

The European Union is forced to strengthen its own energy security under the growing instability at world energy markets and the efforts of individual states to make the energy factor a tool for implementing their foreign policy.

That is why the urgency of finding ways to meet the growing needs of European countries in imported gas in order to ensure their own energy security is beyond doubt.

New complex unpredictable conditions for the formation of foreign economic positions of individual countries, unstable political and economic situation, as well as the risks of infrastructure failure, are forcing EU countries to strive for stability and security of energy supply.

The emergence of new powerful sources of energy supply at the European market within the framework of projects of gas production increase in the Caspian and Mediterranean regions, Central Asia, as well as the development and diversification of transport and energy infrastructure, provide EU countries with a unique opportunity to import pipeline gas.

At the same time, in the coming years, the total capacity of the EU countries to receive and regasify gas should constitute more than 300 billion cubic meters, which, by means of liquefied natural gas, will cover almost half of the gas needs of European countries.

Key words: natural gas, natural gas import, gas pipeline, liquefied natural gas terminal

УДК 323.173: 338.22.021.4

\section{Н. В. Резнікова}

\section{ОГЛЯД ТЕОРЕТИЧНИХ ПІДХОДІВ ДО ІДЕНТИФІКАЦІЇ ЕКОНОМІЧНОЇ МОТИВАЦІЇ ЯК ЧИННИКА ВІДОКРЕМЛЕННЯ І СЕПАРАТИЗМУ}

У статті здійснено комплексний критичний аналіз існуючих теоретичних підходів до ідентифікації економічної мотивації як чинника відокремлення і сепаратизму, з акиентом на виокремленні економічних детермінант сепаратизму. Розкрито мотивачійні інтениії відокремлення та сепаратизму залежно від розміру економіки (велика відкрита економіка та мала відкрита економіка), економічних інтересів суб'єктів господарювання (виробники та споживачі) та соціальних запитів $з$ 
врахуванням потенційного впливу на економічне зростання. Наголошується, щзо сепаратизм, маючи передусім внутрішні передумови, зазнає також впливу з боку акторів геополітичної гри, для реалізації чиї доктрин забезпечення національних інтересів $і$ домінування у світі сепаратистські процеси сприяють досягненню мети, оскільки політично й економічно ослаблені державні утворення не мають достатнього ресурсу для прийняття повністю суверенних рішень, а також зменшують ймовірність утворення політичних союзів, здатних створювати конкуренцію лідерам.

Розглянуто моделі, в яких найістотнішою ідеєю формування ідентичності територій визнано ту, що базується передусім навколо економічних інтересів, а тому й прагнення сепаратистських рухів також зумовлені й визначаються економічними інтересами. Економічний корисливий інтерес (включно з перспективними або обічяними здобутками у майбутньому) є єдиним найістотнішим і найлегітимнішим підгрунтям для просування незалежності на будь-якій території. Сепаратистські політичні спільноти створюються, коли частина населення вбачає відокремлення економічно вигідним. Отже, легітимність руху за незалежність у иілому будується на низиі економічних чинників, як-от частка регіону в національному доходові, абсолютний рівень його розвитку, його торгівля з рештою краӥни, його чисті потоки капіталу з іншими регіонами і його фіскальна автономія

Відсутність єдності у висновках щооо наслідків сепаратизму, проілюстована нами у дослідженні на прикладі чималого обсягу наукової літератури, а також нехтування, на наш погляд, важливими аспектами геополітичних устремлінь потужних країн свідчить про наявність різноспрямованих базових інтересів учасників міжнародних відносин, які $i$ постають фундаментальним базисом прочесів автономізації аж до відокремлення. Серед детермінант підтримки сепаратизму виокремлено: наявність регіональних політичних партій; певну ступінь децентралізації; уявлення про слабкість держави, до складу якої входять сепаратистські регіони. Можливі судження та висновки щзодо економічного підгрунтя відокремлення чи сепаратизму можуть породжуватися внутрішнім конфліктом, слабким керівництвом або формуватися по мірі загострення регіональних асиметрій та економічної кризи.

Ключові моменти на користь великих територіальних одиниць можуть бути зведені до таких: великі економіки сприяють розвитку потужних галузей промисловості; великі економіки забезпечують державний сектор висококваліфікованими службовиями; ринки працюють без адміністративних або торгових кордонів; регіони захищені або убезпечені від зовнішніх потрясінь; диверсифікована економіка дає змогу уникати структурних проблем). Економічні наслідки відокремлення залежатимуть від: ступеня фрагментованості суспільства, інституиійних обмежень, політики, яка використовує або обмежує вигоди від глобалізації.

Ключові слова. відокремлення, сепаратизм, самовизначення, незалежність, економічне зростання, економічні детермінанти, економічна безпека.

DOI 10.34079/2226-2822-2020-10-19-92-104

Постановка проблеми у загальному вигляді та зв'язок із важливими науковими чи практичними завданнями. Як правило, причини спроб автономізації, поглиблення іiі і навіть відокремлення пов'язують передусім з природним прагненням народів до самовизначення. При цьому переважно говорять про відновлення, збереження й розвиток історичної пам'яті, культури, мови та інших складових ідентичності етносу або території. Та все ж, якщо поглянути на останні три десятиліття європейської історії, а також на геополітичні процеси упродовж цього часу, з'ясовується, що таке сприйняття 
теми матиме поверховий характер, міститиме переважно емоційно-суб'єктивну, часом, спекулятивну категорію сприйняття дійсності. Тому дослідники намагаються розгледіти грунтовніші, основоположніші мотиви сепаратистських рухів.

Аналіз останніх досліджень та публікацій. О.Цебенко, проводячи політологічний аналіз форм сепаратизму, виокремлює політичний, економічний, правовий та ідеологічний сепаратизм, відзначаючи визначальною рисою економічного сепаратизму намагання регіону вийти із загальнодержавної економічної системи, розірвати господарські зв'язки, що може супроводжуватись самоізоляцією чи переорієнтацією на зовнішньоекономічних партнерів [40, с.45-46]. На думку I. Рафальського, «відокремлення» або «сецесія» являє собою форму політичного сепаратизму i $\epsilon$ політичним процесом, в ході якого від державного утворення відокремлюється якась його частини, в межах якої створюється нова суверенна держава [37, c.85], тоді як сепаратизм визначається як прагнення окремих груп населення чи організації до відокремлення, відособлення; рух за надання частині держави права автономії чи за її повне відокремлення й створення нової держави. У багатонаціональних державах - це прагнення національних меншин до відокремлення, створення самостійної держави 37, с.84]. У політико-територіальному відношенні, зазначає I. Рафальський, крім сецесії, політичний сепаратизм може також виявлятися у формі іредентизму, тобто відокремленні частини території держави 3 метою приєднання до іншої держави. Теоретико-методологічне значення поняття «сецесія» полягає в наступному: 3 його допомогою досягається можливість теоретичного осмислення закономірностей сепаратистських процесів; це поняття дозволяє доповнювати існуючі типології політичних процесів і значно розширювати сферу застосування порівняльного методу в політичних науках [37, с.85 ]. Цитуючи В. Дівак [34], автор акцентує на тому, що кардинальна розбіжність між обома поняттями залишається у сфері визнання або невизнання легітимності центральної влади. Відтак відокремлення або сецесія $\epsilon$ вужчим поняттям і означає вимогу формального виходу 3 держави, розриву зв'язків із центральною владою з боку якоїсь частини державного утворення на підставі прагнення до створення суверенної держави. За таких умов стає очевидним, що рухи за відокремлення (сецесію) і сепаратистські рухи можуть легко переходити одне в одне на різних етапах своєї еволюції, а їх лідери можуть змінювати цілі, свідомо або несвідомо маніпулюючи змістом цих понять [37, с.80 ]. Базуючись на комплексному використанні здобутків багатьох суміжних наук, Н. Горло з'ясовує сутність досить неоднозначних процесів і явищ сучасності, пов'язаних з визначенням регіоном свого статусу, таких як автономізм, сепаратизм, іредентизм, сецесіонізм [33, с.24], наголошуючи: «якщо мета сепаратистів-сецесіоністів полягає у виході зі складу існуючої держави і створенні власної, то іредентисти прагнуть здійснити сецесію з метою приєднання до сусідньої держави» [33, с.58].

Метою дослідження $є$ комплексний критичний аналіз існуючих теоретичних підходів до ідентифікації економічної мотивації як чинника відокремлення i сепаратизму, з акцентом на виокремленні економічних детермінант сепаратизму.

Виклад основного матеріалу. А. Родрігес-Позе і Р. Сандал [26], ставлячи за мету дослідити вплив економічного чиннику на розвиток сепаратистських інтенцій, проаналізували аргументацію кампаній за референдум у Шотландії. Комісія робочої групи з фіскальних питань, утворена урядом Шотландії, зазначила низку економічних переваг з точки зору існування Шотландії як самостійної держави [13]. Комісія вважала, що незалежна Шотландія матиме краще економічне позиціонування, адже «чимало аналогічних за структурою і величиною країн мають змогу застосовувати усі політичні важелі для досягнення у довготерміновій перспективі значно кращих результатів соціально-економічного розвитку» [13, p. 37]. Нинішня ж неспроможність, на думку 
членів Комісії, мати порівнюваний економічний потенціал зі схожими країнами (Австрія, Данія, Фінляндія, Ірландія, Люксембург, Португалія і Швеція) пояснюється існуючими зв'язками з Великобританією, а тому «незалежність - це шлях до повного розкриття потенціалу Шотландії та усунення обмежень поточної конституційної бази».

У Каталонії Консультаційна рада з національного переходу (Advisory Council for National Transition) - аналог Комісії робочої групи з фіскальних питань у Шотландії - в основних документах аргументувала економічні переваги незалежної держави Каталонія. Згідно з ними незалежність не матиме жодних негативних наслідків для економічного зростання. Наприклад, «поділ між Чеською Республікою і Словаччиною у 1993 році не спровокував особливих проблем [...], їхні економіки не відчули занепаду і продовжували зростати кожна власним шляхом» [18]. Крім того, каталонська держава одразу ж нарощуватиме власні доходи, бо «після трьох століть сплати податків іспанській державі каталонці відчують, що їхні зусилля в економічній сфері безпосередньо впливатимуть на піднесення якості життя громадян Каталонії» [18, p. 12], коли ж «суспільні ресурси управлятимуться у прозоріший і відповідальніший спосіб, добровільні внески у державу значно зростуть» [17, p. 27]. А тому очікувалося, що сепаратизм забезпечить «дивіденд від незалежності», який характеризуватиметься вищим зростанням і процвітанням на нових незалежних територіях.

Водночас, як показують приклади Шотландії і Каталонії, твердження прихильників відокремлення щодо подолання бюрократизації й економічної стагнації мають розбіжності з реальним станом речей і грунтуються передусім на обмежених емпіричних даних із минулого. $€$ небагато досліджень щодо економічних наслідків сепаратизму, а наші знання про вплив незалежності на економічну політику нових країн ще не $\epsilon$ докладними. У переважній частці праць щодо таких питань, як величина країни (зокрема, А. Алесіни у співавторстві з К. Вач'яргою [2] та Е. Спалаорою [1], Г. Армстронга та Р. Ріда [4], А. Прайса [23] або безпосередньо сепаратизму, розглядаються передусім демографічні, політичні або фіскальні аспекти (як то у науковому доробку Д. Берковітца [5], І.С. Ластіка, Д. Мйодовніка і Р.-Дж. Ейдельсон [19], М. Хосойє [16]). Отже, питання про те, чи створює сепаратизм «дивіденд від незалежності», залишається значною мірою недослідженим, хоча приклад Чехії і Словаччини більш ніж показовий, що свідчить про наявність другого мотиву - геополітичного, який ми опускаємо зважаючи на мету статті, в якій увага зосереджуватиметься передусім на внутрішніх аспектах).

Так, М. Хечтер [15, p. 267] у статті під назвою «The Dynamics of Secession», пише: «Сепаратизм (англ. «secessionism») - це вимога формального виходу [3-під юрисдикції] центральної політичної влади з боку суб'єкта або суб'єктів, що входять до складу [держави], на основі претензії на незалежний суверенний статус [...] Відокремлення буде успішним, якщо вихід отримує визнання держави, до складу якої входить суб'єкт (англ. «host state»), i міжнародного співтовариства». Таке визначення сепаратизму (англ. «secessionism») і відокремлення або сецесії (англ. «secession») використовуватиметься надалі.

У моделі М. Хетчера підкреслюється присутність чотирьох послідовних етапів сепаратистського руху, кожен із яких є визначальною перешкодою, які треба подолати: 1) самовизначення регіональної групи; 2) колективні дії у регіоні; 3) детермінанти підтримки сепаратистів; 4) реакція держави, до складу якої входять суб'єктисепаратисти (англ. «host state»).

На кожному етапові наступу на економічну безпеку держави економічні міркування відіграють основоположну роль у визначенні того, чи зможуть прогресувати незалежницькі амбіції. На початкових етапах самовизначення регіональної групи наявність значних природних ресурсів або належних трудових навичок допомагає 
громадянам усвідомити загальні інтереси, що, зрештою, формує спільну ідентичність. Як зазначають Дж. Ван Хейген та Б. Айхенгрін, коли на периферійних територіях поширюється думка, «що тут отримують менше вигод, що надходять від центральної влади, ніж можливих від очікуваних» [31], це сприятиме подальшому самовизначенню групи. Тільки тоді, як стверджує М. Хетчер, чітко окресляться інтереси виробника i споживача, а додаткові культурні й історичні чинники сприятимуть духові єднання. Такі економічні міркування впливають на участь у регіональних колективних діях.

Підтримка сепаратизму на визначальному третьому етапові також має глибокі економічні корені. Вона зазвичай надходила спочатку від представників середнього класу, приватного сектора і сектора послуг. Н. Самбаніс і Б. Мілановіч вважають, що їх поєднує переконання у тому, що особистий добробут не має прямої залежності від зв'язків із центральним урядом або з іншими територіями країни. Тому вони розглядають «свою участь у багатонаціональній державі як таку, що внутрішньо суперечить природі і $є$ серйозною перешкодою для повноцінного розвитку їхньої групи» [29]. Індустріальні ж і сільськогосподарські робітники менш чутливі до сепаратистських настроїв, оскільки їхня праця, їі якість і віддача пов'язані із спільними національними ринками і масштабом економіки, а також періодичною прямою підтримкою від держави. Тому, як переконують Н. Самбаніс і Б. Мілановіч, дотримуючись підходу М. Хечтера, кожна конкретна група керується власним корисливим інтересом у питанні незалежності. Це $\epsilon$ ключовим чинником, який означає, що загальна схильність до сепаратизму виникає незалежно від будь-яких абсолютних умов: «Ця [модель] грунтується на припущенні, що громадяни зажадають відокремлення тільки тоді, коли відчують особисту вигоду. Зазначимо, ця ідея допускає, що підтримка сепаратизму не залежить від рівня економічного розвитку або експлуатації регіону. 3 цього погляду зрозумілішими є націоналістичні вимоги на тлі сепаратистських претензій після відкриття нафти у Біафрі і Шотландії» [ 15, p. 276].

Крім того, додатковими детермінантами підтримки сепаратизму є наявність регіональних політичних партій, певна ступінь децентралізації, а також уявлення про слабкість держави, до складу якої входять сепаратистські регіони (уявлення - висновки - можуть породжуватися конфліктом, слабким керівництвом або економічною кризою).

Реакція ж держави (четвертий етап) на сепаратистські вимоги залежить від передбачуваних економічних наслідків можливого відокремлення однієї частини держави. Вона може вдатися до жорсткої відсічі сепаратизмові або, навпаки, полегшити досягнення незалежності. Але $\epsilon$ i «середній» варіант 3 пропозицією сприятливішої політики щодо рівня фіскальної і політичної автономії, стимулів для лідерів сепаратистів i/або виборців. Але держава завжди (як правило, часто) має змогу застосувати силу 3 усвідомленням того, що це також має власну ціну. Остаточне рішення залежатиме від відносної ціни підтримки єдності держави.

Динамічна модель М. Хечтера пропонує низку важливих варіантів аналізу політичної економії сепаратизму. Найістотнішою є ідея формування ідентичності територій передусім навколо економічних інтересів, а тому й прагнення сепаратистських рухів також зумовлені й визначаються економічними інтересами. Економічний корисливий інтерес (включно 3 перспективними або обіцяними здобутками у майбутньому) є єдиним найістотнішим і найлегітимнішим підгрунтям для просування незалежності на будь-якій території. Сепаратистські політичні спільноти створюються, коли частина населення вбачає відокремлення економічно вигідним. Отже, легітимність руху за незалежність у цілому будується на низці економічних чинників, як-от частка регіону в національному доходові, абсолютний рівень його розвитку, його торгівля 3 рештою країни, його чисті потоки капіталу з іншими регіонами і його фіскальна автономія [7]. Сприятливі комбінації цих чинників визначають імовірність появи і шанси на успіх націоналістичного i/або сепаратистського руху. А тому культурні, історичні й 
етнічні зв'язки (так званий «романтичний націоналізм»), не підсилені економічним стимулом, ніколи не $\epsilon$ достатньою умовою для утвердження самодостатніх сепаратистських рухів.

3 погляду на це не дивно, що переважання ідеї економічного націоналізму над націоналізмом романтичним $\epsilon$ звичайним явищем для сепаратистських рухів за незалежність останнього часу [35; 36; 38; 39], наприклад, у Каталонії або Шотландії. Зокрема, Національна партія Шотландії (Scottish Nationalist Party (SNP)), яка мала тільки 11\% голосів шотландських виборців у 1970 році, побачила, як зростає її підтримка, коли після чотириразового подорожчання ціни на нафту після війни Судного дня 1973 року британський уряд зініціював закони, згідно з якими 90\% додаткових прибутків від нафтових покладів, розташованих поблизу шотландського узбережжя, надходитиме до урядової скарбниці. Під гаслом «Ця нафта шотландська» SNP здобула понад 30\% голосів шотландських виборців на виборах 1974 року. Така зміна в електоральній підтримці притаманна і партії «Північна ліга» в Італії. Цей політичний рух, побудований на ідеї «романтичного націоналізму», спрямованій на відродження так званої «паданської» держави, перебував на узбіччі електоральних уподобань і пережив злет, щойно його керівництво на чолі з Умберто Боссі розпочало мову про «репатріацію» податків до тих регіонів, де вони сплачуються [17]. Такі ж фіскальні аргументи популярного гасла «ІІпанія нас обкрадає» пронизують нинішню ідею незалежності Каталонії [ $17 ; 18]$.

М. Букман також надає дані про значення економічних прагнень для сепаратистських рухів. В емпіричному дослідженні 37-ми сепаратистських рухів у всьому світі вона з'ясувала, що основним джерелом легітимності їх $є$ економічний стимул, до якого додаються культурні, мовні або інші «романтичні» аргументи. Дослідник визначає, що подібний набір економіних «образ» зумовив розпад Югославії, Чехословаччини і СРСР. Але слід пам'ятати, що підтримка сепаратизму, заснована на «економічному корисливому інтересові», може залежати не лише від перспектив відчутних короткострокових вигод, як-от нафта Північного моря або частка у податкових надходженнях країни, а й від прагнення усунути справжні або уявні правові або політичні перешкоди для процвітання. Такий стимул часто виникає в часи економічних або політичних криз, коли різні бачення реструктуризації економіки можуть зумовити значні розбіжності та прискорити події.

Моделювання потенційних вигод від відокремлення стає дедалі популярним 3 акцентом на економічні переваги як чинника сепаратизму. Такі спроби розпочалися у 1980-х роках, коли чимало досліджень присвячувалися моделюванню не тільки чинників, а й прогнозам наслідків ширшої автономії або незалежності. В одній із найперших праць Дж.М. Бучанана і Р.Л. Фейза [9] вжито термін «внутрішнього виходу» периферійного регіону в межах єдиної країни. Згідно $з$ теоретичною моделлю авторів регіон може голосувати за вихід із країни, але вже без наступного доступу до будь-яких внутрішніх трансфертів і суспільних товарів. Моделювання засвідчило, що за умови відокремлення багатші регіони матимуть сприятливішу ситуацію, ніж бідніші; внаслідок цього загроза відокремлення (передусім з метою скорочення податкового навантаження) буде ймовірнішою, якщо вона надійде від багатого регіону. У підсумку (або за умови відокремлення багатого регіону, або зниження податків для всіх) бідніші регіони перебуватимуть у програші. Цей висновок став точкою відліку для низки додаткових моделей - Д. Берковіца [5], П. Болтона і Дж. Роланда [6], С. Ластіка, Д. Мйодовніка і Р.-Дж. Ейдельсон [19], В. Анесі і Д. Дондера [3], які надали нові варіації економічних наслідків відокремлення.

Попри значну кількість теоретичних підходів емпіричний аналіз характеру впливу відокремлення (сецесіі) на економічні показники нових незалежних країн $є$ відносно обмеженим. У літературі здебільшого йдеться про супутні питанням, як-от роль 
величини країни. Останніми роками точаться суперечки щодо того, чи мають менші країни кращі показники ефективності, ніж більші. Відповідні теорії, як правило, намагаються точно визначити вигоду i ціну для великих i малих країн, якими встановлюється рівновага, що максимізує чисті потенційні прибутки урядів.

Основну дихотомію дуже досконало виражено ще у Шарля Монтеск'є в його праці «Про дух законів» (1748р.), що аналізується А.М. Колером, Б.К. Міллером і Г.С. Стоуном [22, р.131]: «Якщо республіка мала, іiі знищує іноземна сила; якщо вона велика, iii руйнує внутрішня недосконалість. На цю подвійну незручність однаково наражаються демократії та аристократії, добрі вони чи погані. Зло тут у ньому самому, $\mathrm{i}$ жодна з форм не може його виправити».

В аргументах на користь великих країн підкреслюється їхня здатність бути динамічнішими, проактивнішими і стійкішими до зовнішніх потрясінь. Це зумовлено вигодами економік більшого масштабу і величини, де нижча питома ціна суспільних товарів, легше утворюються спеціалізовані, конкурентні сектори і забезпечуються високі стандарти громадських послуг [2]. Великі країни вважаються також краще захищеними від економічних негараздів 3 погляду на їхні великі резерви [2; 4]. Аргументи на користь більших країн містять також їхню прискіпливішу обережність щодо ризиків й кращу захищеність від ризиків, кращу здатність до перспективного планування, а також величину і диверсифікованість, достатню, щоб обмежувати появу структурних проблем на кшталт Данської хвороби [4].

Водночас більші країни також часто здатні на додаткові витрати, пов'язані 3 функціонуванням потужних керівних органів. Такі витрати можуть перекрити потенційні вигоди, пов'язані з величиною, оскільки чисельне населення зазвичай $\epsilon$ різноманітнішим в етнічному, мовному сенсах, в уподобаннях. Великі країни можуть стикатися також зі складнішими проблемами, пов'язаними з розбудовою інституцій, колективними діями і виробництвом суспільних товарів. Хто ж підтримує малі країни, то звертають увагу на такі їхні позитивні риси, як-от більша схильність до співпраці, згуртованість, інноваційність і легкість в управлінні порівняно з більшими країнами. Малі країни є відкритішими для торгівлі i, можливо, здатні краще знаходити i заповнювати спеціальні ринкові ніші. Зрештою, у малих країнах менший бюрократичний апарат, їм не потрібні «додаткові відомства для обслуговування самої організації», що скорочує їхні внутрішні адміністративні витрати [32].

Ключові моменти на користь великих територіальних одиниць можуть бути зведені до таких: великі економіки сприяють розвитку потужних галузей промисловості; великі економіки забезпечують державний сектор висококваліфікованими службовцями; ринки працюють без адміністративних або торгових кордонів; регіони захищені або убезпечені від зовнішніх потрясінь; диверсифікована економіка дає змогу уникати структурних проблем). Економічні наслідки відокремлення не лишають місця оптимізму, адже: фрагментованість суспільства шкодить економіці й інститутам; різноманітність уподобань ускладнює роботу інститутів і виробництво суспільних товарів; протекціонізм скорочує вигоди від глобалізації; бюрократія стає надмірною і може бути обтяжливою і складною.

Згідно 3 теоріями про величину країни зазначені вище протилежні сили створюють рівноважну систему iі міжнародних кордонів, всередині яких економічні вигоди масштабу і величини врівноважуються ціною внутрішньої фрагментованості й бюрократії [1]. Одна сукупність сил спричиняє централізацію і розширення країни, створюючи при цьому вигоди для багатства й ефективності; друга - занепад і сепаратизм через різноманітність уподобань й обтяжливий адміністративний апарат. Тому основні сили, знову ж таки, постають на грунті корисливого інтересу. 
Емпіричні дослідження щодо оптимальної величини країни надають низку висновків для роздумів. У деяких літературних джерелах, як у А.К. Роуза [27], не зазначено жодної різниці між економіками великих і малих країн. Використовуючи панель даних про 200 країн за 40 років, А.К. Роуз не бачить емпіричного зв'язку між різницею у величині країни й ефективністю економіки за винятком відкритості торгівлі, де малі країни мають кращі показники. 3 точки зору сепаратизму це означає, що нові незалежні (малі) держави не можуть розраховувати на значні зміни показників зростання й ефективності економіки, що підриває аргумент на користь того, що вони житимуть краще за умови самостійності.

В інших дослідженнях - В. Істерлі і А. Краайа [11], Д. Сальваторе, М. Светлічіча і Дж.П. Дам'яна [28] - навпаки, зазначено, що величина країни має значення для ефективності економіки. Але серед дослідників немає згоди щодо напряму і масштабу цього ефекту, звідки напрошується висновок, що зв'язок між величиною країни й економічними результатами є складним і поки що не зовсім зрозумілим.

Досліджень, присвячених безпосередньому аналізові реальних наслідків потенційного відокремлення [регіонів] у конкретних країнах, навіть ще менше, він насамперед стосується гіпотетичних i/або майбутніх, а не реальних або історичних прикладів. Такий аналіз є у праці Дж.Бросіо і Ф. Ревеллі [8], автори якої оцінюють вплив можливого відокремлення від італійської держави 19-ти іiі регіонів, розраховуючи потенційні економічні збитки і здобутки для медіанного виборця у кожному регіонові за три періоди часу. Хоча Дж.Бросіо і Ф. Ревеллі не пропонують чітких висновків про сукупний чистий ефект для Італії від відокремлення, з результатів їхнього аналізу зрозуміло, що за умови можливого розпаду італійської держави багаті регіони на півночі країни отримають значні вигоди від відокремлення. Бідні регіони півдня країни, навпаки, програють. А. Прайс і Б. Левінгер [23] також моделюють економічні наслідки від виникнення незалежної «Республіки Уельс» й отримують позитивний вплив відокремлення: якби Уельс здобув незалежність у 1989 році, він став би на 39\% багатшим у 2011 році незважаючи на відносну бідність порівняно з рештою Великобританії на початку періоду [незалежності].

Е. Сполаоре і Р. Ваш'ярг [30] моделюють економічний результат від злиття двох сусідніх країн, коли дві країни об'єднують ринки, але продовжують взаємний експорт, або ж шляхом «повної інтеграції», коли вони зливаються в єдине ціле. Використовуючи велику вибірку країн, вони роблять висновок, що будь-яка пара країн отримує додаткові $0,12 \%$ річного зростання за умови територіального злиття, але, навпаки, втратить $0,11 \%$ річного зростання за «повної інтеграції». П. Кольє і А. Дж. Венейбл [10] стверджують, що надмірна фрагментація Африки на південь від Сахари шкодить зростанню, зменшує можливості для великомасштабної індустріалізації, що поставило цей регіон на шлях сировинної спеціалізації за відсутності значних економік масштабу.

I, нарешті, як відзначають Е. Мігель, С. Сатьяната й Е. Сердженті [20], Дж.Д. Фірон і Д.Д. Лейтин [12], Дж.К. Мердок і Т. Сандлер [21], відокремлення майже не можливо домогтися без конфліктів, які іноді переростають у громадянську війну. Громадянська непокора спричиняє відчутне руйнування економіки і загалом асоціюється з низьким рівнем зростання. Масштаб впливу конфлікту на економіку визначається його інтенсивністю, тривалістю і термінами.

Висновки. У нашому аналізові наголошується, що сепаратизм, маючи передусім внутрішні передумови, зазнає також впливу з боку акторів геополітичної гри, для реалізації чиїх доктрин забезпечення національних інтересів і домінування у світі сепаратистські процеси сприяють досягненню мети, оскільки політично й економічно ослаблені державні утворення не мають достатнього ресурсу для прийняття повністю 
суверенних рішень, а також зменшують ймовірність утворення політичних союзів, здатних створювати конкуренцію лідерам.

Відсутність єдності у висновках щодо наслідків сепаратизму, проілюстована нами у дослідженні на прикладі чималого обсягу наукової літератури, а також нехтування, на наш погляд, важливими аспектами геополітичних устремлінь потужних країн свідчить про наявність різноспрямованих базових інтересів учасників міжнародних відносин, які і постають фундаментальним базисом процесів автономізації аж до відокремлення.

\section{Список використаної літератури}

1. Alesina A. On the Number and Size of Nations Electronic resource] / A. Alesina, E. Spolaore // The Quarterly Journal of Economics. — 1997. — Vol. 112, Issue 4. — P. 10271056. - Mode of access : https://academic.oup.com/qje/articleabstract/112/4/1027/1911699?redirectedFrom=fulltext

2. Alesina A. Openness, Country Size and Government [Electronic resource] / A. Alesina, R. Wacziarg // Journal of Public Economics. — 1998. — Vol. 69. — P. 305-321. — Mode of access : https://www.nber.org/papers/w6024

3. Anesi V. Voting Under the Threat of Secession: Accommodation vs. Repression [Electronic resource] / V. Anesi, P. De Donder // Social Choice and Welfare. - 2013. - Vol. 41. — P.241-261. — Mode of access: https://link.springer.com/article/10.1007/s00355-012$0682-2$

4. Armstrong H.W. Small States \& Small Island States : Implications of Size, Location \& Isolation for Prosperity / H. W Armstrong, R. A Read // .On the Edge of the Global Economy: Implications of Economic Geography for Small- \& Medium-Sized Economies at Peripheral Locations. editor / Jacques Poot. Cheltenham : Edward Elgar, 2004. P. 191-223. Mode of access: http://www.research.lancs.ac.uk/portal/en/publications/small-states--smallisland-states(b8307c0b-8d86-44ef-ad6a-557fb916f4db)/export.html

5. Berkowitz D. Regional Income and Secession: Centre-periphery relations in emerging market economies [Electronic resource] / D. Berkowitz // Regional Science and Urban Economics. - 1997. - Vol. 27, Issue 1. - P. 17-45. - Mode of access : https://www.sciencedirect.com/science/article/abs/pii/S0166046296021436

6. Bolton P. The Breakup of Nations: a political economy analysis [Electronic resource] / P. Bolton, G. Roland // Quarterly Journal of Economics. - 1997. — Vol. 112, Issue 4. - P. 1057-90. - $\quad$ Mode of access: https://econpapers.repec.org/article/oupqjecon/v_3a112_3ay_3a1997_3ai_3a4_3ap_3a10571090..htm

7. Bookman M. The Economics of Secession / M. Bookman. - Basingstoke : Macmillan Press, 1993. - $262 \mathrm{p}$.

8. Brosio G. The Political Economy of Regional Opting Out: Distributive implications of a prospective Europe of regions [Electronic resource] /G. Brosio, F. Revelli // Economics of Governance. - 2003. - Vol.4. - P. 127 - 142. - Mode of access : https://link.springer.com/article/10.1007/s 101010200053

9. Buchanan J.M. Secession and the Limits of Taxation: toward a theory of internal exit / J.M. Buchanan, R.L. Faith // American Economic Review. - 1987. — Vol. 77, Issue 5. — P. 1023-1031.

10. Collier P. Trade and Economic Performance: does African fragmentation matter? [Electronic resource] / P. Collier, A.J. Venables. - Cape Town, 2008. - Mode of access : http://citeseerx.ist.psu.edu/viewdoc/download?doi=10.1.1.532.108\&rep=rep1\&type=pdf

11. Easterly W. Small States, Small Problems? Income, Growth and Volatility in Small States [Electronic resource] / W. Easterly, A. Kraay // World Development. — 2000. — 


Vol. 28, Issue $\quad 11 . \quad-\quad$ P. $\quad$ 2013-2027. $\quad$ - $\quad$ Mode of

access : https://www.researchgate.net/publication/222514869_Small_States_Small_Problems _Income_Growth_and_Volatility_in_Small_States

12. Fearon, J. D. Ethnicity, insurgency, and civil war [Electronic resource] / J. D. Fearon, D.D. Laitin // American Political Science Review. - 2003. - Vol. 97, Issue 1. - P. 75-90. — Mode of access: http://www.uky.edu/ clthyn2/PS439G/readings/fearon_laitin_2003.pdf

13. Fiscal Commission Working Group [Electronic resource] First Report Macroeconomic Framework // The Scottish Government. - 2013. — February 11. - Mode of access

https://www.webarchive.org.uk/wayback/archive/20170701074158/www.gov.scot/Publicatio ns/2013/02/3017

14. Gold T. W. The Lega Nord and Contemporary Politics in Italy / T. W. Gold. Basingstoke : Palgrave Macmillan, 2003. - 188 p.

15. Hechter M. The Dynamics of Secession [Electronic resource] / M. Hechter // Acta Sociologica. - 1992. - Vol. 35, Issue 4. - P. 267-283. Mode of access : https://www.academia.edu/20583253/The_Dynamics_of_Secession

16. Hosoe M. Political Economics of Regional Integration-Secession and Representative Elections [Electronic resource] / M. Hosoe // Journal of Economics, Kumamoto-Gakuen University. - 2011. - Vol. 18, Issue 1-2. - P. 17-37.

17. L’Administració tributària de Catalunya [Electronic resource]. - Barcelona : Generalitat de Catalunya, 2013. - Rapport Vol.2. - Mode of access: https://presidencia.gencat.cat/web/.content/ambits_actuacio/consells_assessors/catn/informes/1 $\underline{\text { libre blanc_angles.pdf } 2}$

18. Les relacions de cooperació entre Catalunya i l'Estat espanyol [Electronic resource].. - Barcelona : Generalitat de Catalunya, 2013. - Rapport no. 3. - Mode of access : https://www.yumpu.com/en/document/view/52805375/les-relacions-de-cooperacio-entrecatalunya-i-lestat-espanyol

19. Lustick I. S. Secessionism in Multicultural States: Does Sharing Power Prevent or Encourage It? [Electronic resource] / I. S. Lustick, D. Miodownik, R. J. Eidelson // American Political Science Review. - 2004. - Vol. 98, Issue 2. - P. 209-229. — Mode of access : https://www.polisci.upenn.edu/ps-i/publications/LusMioEid.pdf

20. Miguel E. Economic shocks and civil conflict: An instrumental variables approach [Electronic resource] / E. Miguel, S. Satyanath, E. Sergenti // Journal of Political Economy. 2004. - Vol. 112, Issue 4. - $\quad$ - P. 725-753. — Mode of access : http://data.nber.org/ens/feldstein/Papers/_Paper_Economic_Shocks_and _Civil_Conflict.pdf

21. Murdoch J. C. Civil Wars and Economic Growth: Spatial Dispersion [Electronic resource] / J. C. Murdoch, T. Sandler // American Journal of Political Science. - 2004. — Vol. 48, Issue 1. - $\quad$ P. 138-151. - Mode of access : https://ideas.repec.org/a/wly/amposc/v48y2004i1p138-151.html 22

22. On the laws in their relation with defensive forse // Montesquieu: The Spirit of the Laws / ed. by A. M. Cohler, B. C. Miller, H. S. Stone. - Cambridge : Cambridge University Press, 1989. - P.131-137.

23. Price A. The Flotilla Effect: Small economies through the eye of the storm [Electronic resource] / A. Price, B. Levinger. - Mode of access : https://issuu.com/plaid/docs/flotilla_effect___adam_price_and_ben_levinger

24. Reznikova N. Projections of deglobalization in the contemporary international economic relations in the context of the paradigm of globalism / N. Reznikova, O. Ivashchenko // Вісник Маріупольського державного університету. Серія: Економіка. - 2018. - Вип.15. - C.98-106; Reznikova N. Projections of deglobalization in the contemporary international 
economic relations in the context of the paradigm of globalism / N. Reznikova, O. Ivashchenko // Visny`k Mariupol`s`kogo derzhavnogo universy`tetu. Seriya: Ekonomika. - 2018. - Vyp.15. - S.98-106.

25. Reznikova N. The Policy of Economic Nationalism: from Origins to New Variations of Economic Patriotism / N. Reznikova, V. Panchenko, O. Bulatova // Baltic Journal of Economic Studies. - 2018. - Vol. 4, № 4. - P. 274-281.

26. Rodríguez-Pose A. From identity to the economy: analysing the evolution of the decentralisation discourse [Electronic resource] / A. Rodríguez-Pose, R. Sandall // Environment and Planning C: Government and Policy. - 2008. - Vol. 26, Issue 1. - P. 5472. — Mode of access: https://journals.sagepub.com/doi/10.1068/cav2

27. Rose A. K. Size Really Doesn't Matter: In search of a national scale effect [Electronic resource] / A.K. Rose // Journal of the Japanese and International Economies. - 2006. Vol. 20, Issue 4. - P. 482-507. — Mode of access : https://www.nber.org/papers/w12191

28. Salvatore D. Small Countries in a Global Economy: New challenges and opportunities / D. Salvatore, M. Svetličič, J. P. Damijan. - London : Palgrave Macmillan, 2001. $-306 \mathrm{p}$.

29. Sambanis N. Explaining regional autonomy differences in decentralized countries [Electronic resource] / N. Sambanis, B. Milanovic // Comparative Political Studies. — 2014. - Vol. 47, Issue 13. - P. 1830-1855. — Mode of access : https://www.semanticscholar.org/paper/Explaining-Regional-Autonomy-Differences-inSambanis-Milanovic\%CC\%81/d9a47d22176761edd6dbfec9c22192d443f1af20

30. Spolaore E. Borders and Growth [Electronic resource] / E. Spolaore, R. Wacziarg // Journal of Economic Growth. - 2005. - Vol. 10, Issue 4. - P. 331-386. — Mode of access : https://ideas.repec.org/p/ecl/stabus/1761.html

31. Van Hagen J. Federalism, fiscal restraints, and European monetary union [Electronic resource] / J. Van Hagen, B. Eichengreen // American Economic Review. - 1996. — Vol. 86, № 2. — P.134-138. — Mode of access : https://www.jstor.org/stable/2118110?seq=1

32. Wittman D. Nations and States: Mergers and acquisitions; dissolutions and divorce [Electronic resource] / D. Wittman // Economics and Conflict. - 1991. — Vol. 81, Issue 2. P. 126-129. - Mode of access : http://ideas.repec.org/a/aea/aecrev/v81y1991i2p126-29.html

33. Горло Н. В. Функціональні та концептуальні моделі політики іредентизму [Електронний ресурс] : дис. ... д-ра політ. наук : спец. 23.00.02 / Наталя Віталіївна Горло; Львів. нац. ун-т ім. Івана Франка. - Львів, 2019. - 2019. - Режим доступу : https://www.lnu.edu.ua/wp-content/uploads/2019/09/dis_horlo.pdf ; Horlo N. V. Funktsionalni ta kontseptualni modeli polityky iredentyzmu [Elektronnyi resurs] : dys. ... d-ra polit. nauk : spets. 23.00.02 / Natalia Vitaliivna Horlo; Lviv. nats. un-t im. Ivana Franka. - Lviv, 2019. 2019. - Rezhym dostupu : https://www.lnu.edu.ua/wp-content/uploads/2019/09/dis horlo.pdf

34. Дівак В. Сепаратизм як феномен сучасної політики: політологічні та правові аспекти : моногр. / В. Дівак. - Київ : Логос, 2010. - 224 с. ; Divak V. Separatyzm yak fenomen suchasnoi polityky: politolohichni ta pravovi aspekty : monohr. / V. Divak. - Kyiv : Lohos, 2010. - $224 \mathrm{~s}$.

35. Панченко В. Г. Методологічні засади економічного націоналізму / В. Г. Панченко, Н. В. Резнікова // Економіка та держава. - 2017. - № 7. - С. 4-8. ; Panchenko V. H. Metodolohichni zasady ekonomichnoho natsionalizmu / V. H. Panchenko, N. V. Reznikova // Ekonomika ta derzhava. - 2017. - № 7. - S. 4-8.

36. Панченко В.Г. Політика економічного націоналізму: від витоків до нових варіацій економічного патріотизму / В. Г. Панченко, Н. В. Резнікова // Економіка та держава. - 2017. - № 8. - C. 4-8. ; Panchenko V.H. Polityka ekonomichnoho natsionalizmu: vid vytokiv do novykh variatsii ekonomichnoho patriotyzmu / V. H. Panchenko, N. V. Reznikova // Ekonomika ta derzhava. - 2017. - № 8. - S. 4-8. 
37. Рафальський I. Самовизначення та сепаратизм. Питання теорії / I. Рфальський // Наукові записки Інституту політичних і етнонаціональних досліджень ім. І. Ф. Кураса. - 2014. - Вип. 4-5. - С. 78-93. ; Rafalskyi I. Samovyznachennia ta separatyzm. Pytannia teorii / I. Rfalskyi // Naukovi zapysky Instytutu politychnykh i etnonatsionalnykh doslidzhen im. I. F. Kurasa. - 2014. - Vyp. 4-5. - S. 78-93.

38. Резнікова Н. В. Теоретико-методологічні засади визначення економічної залежності в умовах двополярного зонування світової економіки / Н. В. Резнікова // Зовнішня торгівля: економіка, фінанси, право. - 2012. - № 4. - C. 38-42. ; Reznikova N. V. Teoretyko-metodolohichni zasady vyznachennia ekonomichnoi zalezhnosti $\mathrm{v}$ umovakh dvopoliarnoho zonuvannia svitovoi ekonomiky / N. V. Reznikova // Zovnishnia torhivlia: ekonomika, finansy, pravo. - 2012. - № 4. - S. 38-42.

39. Резнікова Н.В. Діалектика національного та глобального в умовах міжкраїнної взаємозалежності / Н.В. Резнікова // Економіка та держава. - 2012. - № 9. - С. 8-11; Reznikova N.V. Dialekty`ka nacional’nogo ta global’nogo $\mathrm{v}$ umovax mizhkrayinnoyi vzayemozalezhnosti / N.V. Reznikova // Ekonomika ta derzhava. - 2012. - \# 9. - S. 8-11.

40. Цебенко О. Форми вияву сепаратизму: теоретико-методологічний аспект / О. Цебенко // Українська національна ідея: реалії та перспективи розвитку. - 2014. Вип. 26. - С. 44-51. ; Tsebenko O. Formy vyiavu separatyzmu: teoretyko-metodolohichnyi aspekt / O. Tsebenko // Ukrainska natsionalna ideia: realii ta perspektyvy rozvytku. - 2014. Vyp. 26. - S. 44-51.

Стаття надійшла до редакції 17.03.2020.

\section{N. Reznikova}

\section{A REVIEW OF THEORETICAL APPROACHES TO IDENTIFICATION OF THE ECONOMIC MOTIVATION AS A FACTOR OF SECESSION AND SECESSIONISM}

The article contains a comprehensive critical analysis of the existing theoretical approaches to identification of the economic motivation as a factor behind secession and secessionism, with emphasis on outlining the economic determinants of secessionism. The motivation-based intentions of secession and secessionism are defined depending on the economy size (a large open economy and a small open economy), economic interests of business entities (producers and consumers) and social demands with accounting to the potential impact on economic growth. It is stressed that secessionism, which background is essentially internal, is also subject to influences from geopolitical actors whose doctrinal goal of securing national interests and global domination finds support in secessionist processes, because politically and economically weak state formations, lacking the sufficient resource for taking totally sovereign decisions, are unlikely to be able to create political alliances capable to compete with leaders.

Models are explored built on the argument that because economic interests are the foundational idea in forming territorial identities, intentions of secession movements are also reliant on and driven by economic interests. The economic mercenary interest (including promised gains in future) is the most solid and legitimate ground for promoting independence in any territory. Secessionist political communities will be formed when secession becomes economically beneficial in the eyes of a part of the population. So, the legitimacy of an independence movement builds on a number of economic factors like the region's share in the national income, the absolute level of the region's development, the region's trade with the rest of the country, its net capital flows with other regions and its fiscal autonomy.

Lack of agreement in the conclusions about consequences of secessionism, illustrated by us in the study based on a large scope of the research literature, and overlooking, as we believe, of important aspects of geopolitical intentions of powerful countries are an indication of 
multidirectional core interests of the international relations' parties, which lay the firm basis for autonomy seeking, until the eventual secession. The determinants of secessionism support are summed up as follows: the existence of regional political parties; a certain degree of decentralization; ideas about the weakness of the state in which secessionist regions are incorporated. Opinions and conclusions about the economic background of secession or secessionism may be possibly born by an internal conflict or weak administration, or may be formed as regional asymmetries and economic crises aggravate.

Key points in favor of large territorial units can be summed up as follows: large economies lay fertile grounds for the development of powerful industries; large economies can supply the public sector with high skilled officials; large markets can work without administrative or trade borders; the regions can be protected or secured from external shocks; a diversified economy is capable to avoid structural problems. The economic consequences of secession will depend on: the degree of society's fragmentation; institutional constrains, policies making use of or limiting the benefits of globalization.

Keywords: secession, separatism, economic determinant, economic security, economic effect.

УДК 378.1.014.24

Y. I. Chentukov

T. V. Marena

\section{HIGHER EDUCATION INTERNATIONALIZATION AS A FACTOR OF IMPROVING UNIVERSITY COMPETITIVENESS}

The paper dwells on estimation of the relationship between internationalization and competitive advantages of higher education institutions on the example of three European universities (University of York, University of Tartu, Vytautas Magnus University), and determining to what extent internationalization impacts university competitiveness. It is stated that the rank and the score of the university in world universities rankings can be considered as the most generalizing and comprehensive indicators of the university competitiveness level. It is found out that most of the world universities rankings take into account indicators that characterize university's international activity. Analysis of the overall score of three European universities and the indicators of their internationalization shows that an increase in internationalization indicators entails an increase in the overall score of the university and its improved positions in the corresponding rankings. Comparing universities' data on international students and international staff demonstrates that these indicators matter for the overall score of the university by QS World University Rankings and consequently for its competitiveness. The comparative analysis of internationalization profile of the universities made it possible to identify the specific constituents of the universities' success in the field of internationalization progress and obtaining competitive advantages.

Key words: higher education internationalization, university competitiveness, universities rankings, international faculty, international students.

DOI 10.34079/2226-2822-2020-10-19-104-112

The terms of tough competition in which universities operate all over the world require, on the one hand, the expansion of educational services markets through the internationalization of educational activities, and on the other hand, finding the ways of enhancing the level of 